\title{
Transaction
}

\section{The Use of Weakly Acidic Spent Bathwater Mixed with Electrolyzed Water for Laundry}

\author{
Tetsuya Takahashi ${ }^{* 1}$, Yoko Tsurunaga ${ }^{* 1}$, Yuji Aso $^{* 2}$, and Tetsuo Kondo ${ }^{* 3}$ \\ ${ }^{* 1}$ Faculty of Education, Shimane University, 1060 Nishikawatsu-cho, Matsue, Shimane 690-8504, Japan \\ ${ }^{*}$ Department of Biobased Materials Science, Kyoto Institute of Technology, Matsugasaki, Sakyo-ku, \\ Kyoto 606-8585, Japan \\ ${ }^{* 3}$ Faculty of Agriculture, Kyushu University, 6-10-1, Hakozaki, Higashi-ku, Fukuoka 812-8581, Japan
}

\begin{abstract}
This study was conducted to develop a method for reusing of spent bathwater in Japan which was disinfected by weakly acidic electrolytic treatment. Electrolyzed water obtained from electrolytic treatment without a diaphragm (single cell) was diluted with spent bathwater and used to launder fabrics. The spent bathwater did not remove dirt from the fabrics well, but it effectively sterilized the washed fabrics. The detergent efficiency was found to decrease by about $5 \%$ when spent bathwater was used when compared to non-treated spent bathwater. The decreased detergent efficiency was believed to be caused by reduced foaming and affinity. To obtain a sufficient sterilization effect without decreasing detergent efficiency, untreated spent bathwater was used for washing, after which spent bathwater mixed with electrolyzed water was used for rinsing. Even when rinse times as short as one cycle for $3 \mathrm{~min}$ were used, this method led to sufficient sterilization of fabrics for laundry. Additionally, odor testing using an odor concentration meter and evaluation by a monitor panel showed that electrolytic treatment markedly decreased the odor level of the test fabrics. Overall, these findings indicated that bacteria on fabrics could be effectively attenuated with no decrease in detergent efficiency if electrolyzed water diluted with spent bathwater was used for rinsing after washing with untreated spent bathwater.
\end{abstract}

(Received 5 November, 2011 ; Accepted 27 January, 2012)

\section{Introduction}

Awareness of water saving has increased and $57 \%$ of the population of Japan now reportedly use spent bathwater for laundry [1]. However, the use of Japanese spent bathwater for washing often results in malodor attaching to the clothing. The optimal temperature for propagation of most bacteria is $30-37{ }^{\circ} \mathrm{C}$; therefore, spent bathwater is a viable environment for bacteria. Moreover, mold contamination also occasionally causes problems in laundry machines. Furthermore, spent bathwater contains large amounts of bacteria, including harmful organisms such Legionella [2,3]. Although sodium hypochlorite as a chlorine bleach has disinfection effect, it cannot be used for colored cloths and in addition it has irritation against the skin due to its strong oxidation activity. It is also known for having trihalomethane generation and metal corrosion behaviors [4-7].

With such backgrounds, the authors focused attention on electrolytic treatment [8,9] based on nondiaphragm electrolytic process with comparatively high safety, in order to utilize spent bathwater in a sanitary and odorless manner. We proposed a novel method, in which the electrolytic treatment based on non-diaphragm process is applied to spent bathwater, and the spent bathwater after the treatment is utilized for washing [10]. We examined the disinfection effect of this process on the spent bathwater and Escherichia coli., and also examined the disinfection effect on washed cloths after washing them using spent bathwater mixed with electrolyzed water [10]. However, the detergent effect of these weakly acidic electrolyzed waters has not been examined when used for laundry. Therefore, this study investigated the detergent effect of spent bathwater mixed with electrolyzed water obtained by a non-diaphragm process (single cell) used for laundry. In addition, the odor attached to fabrics after laundering was quantified.

\section{Experimental}

\subsection{Samples}

\subsubsection{Artificially soiled fabrics}

Artificially soiled cotton made by the Laundry Research Association of Japan and artificially soiled cotton, polyester, silk, wool, and acrylic made by Testfabrics, Inc. (United State) were used in laundry 
Table 1 Compositions of pastes for artificially soiled fabrics.

\begin{tabular}{lc|lr}
\hline The Laundry Research Association of Japan & \multicolumn{2}{c}{ Testfabrics, Inc. (U.S.) } \\
\hline Ingredient & Amount & Ingredient & Amount \\
\hline \hline Oleic acid & $24.5 \%$ & Kelex (Sodium Alginate Thickner) & $1.30 \%$ \\
Triolein & $20.9 \%$ & Corn starch (\#10 Pearl Starch) & $2.20 \%$ \\
Cholesterololeate & $16.0 \%$ & Water (N.J. tap) & $72.40 \%$ \\
Liquid paraffin & $3.1 \%$ & Mineral oil (Penreco Drakeol \#21) & $14.00 \%$ \\
Squalene & $3.1 \%$ & Oleic acid & $0.42 \%$ \\
Cholesterol & $2.1 \%$ & Morpholine & $0.36 \%$ \\
Inorganic dirt (clay) & $29.8 \%$ & Vegitable fat & $1.70 \%$ \\
Carbon black & $0.5 \%$ & (Unemulsified Covo -Lever Bros.) & \\
& & Butanol & $0.30 \%$ \\
& & Solvesso 150 & $4.40 \%$ \\
& & Ethyl cellulose & $0.70 \%$ \\
& & Carbon black (Degussa) & $0.70 \%$ \\
\hline
\end{tabular}

experiments. The former fabrics were already cut to a size of $5 \times 5 \mathrm{~cm}$. The latter fabrics were used after cutting to a size of $5 \times 5 \mathrm{~cm}$. Table 1 shows the compositions of the soil pastes on the artificially soiled fabrics used in this experiment.

\subsubsection{Films}

General-purpose cellophane \# 500 (Futamura Chemical Co., Ltd., Japan) and Teijin Tetron film HS-75 $\mu \mathrm{m}$ (Teijin DuPont Films Japan Ltd. Japan) were used. Neither film received any surface treatment.

\subsubsection{Spent bathwater}

Spent bathwater was collected at $7.00 \mathrm{AM}$ in mid-April from a household composed of a husband, wife, and a junior high school student (June, 2010). The dimension of a used bathtub is W125 $\times$ D63 $\times \mathrm{H} 50 \mathrm{~cm}$, accommodating ca. $220 \mathrm{~L}$ of hot water. Additional heating is not applied. The water is the spent bathwater with good transparency, without floating of scurf. At a household used as a sample, family members take a bath every day, and practice body-washing before entering the bathtub. Meanwhile, this household replaces water for the bathtub every day, and practices the cleaning of the bathtub also every day. This can be said as a typical household in Japan.

\subsection{Electrolytic treatment}

Water was treated using a previously described [10] non-diaphragm electrolytic process (Hokuty Co., Ltd., Piamini). Briefly, different concentrations $(0.5 \mathrm{~N}, 1.0 \mathrm{~N}$, $2.0 \mathrm{~N}$, and $3.0 \mathrm{~N}$ ) of $25 \mathrm{~mL}$ of $\mathrm{HCl}$ aqueous solution were injected into an electrolysis cell, after which electrolytic treatment was conducted for a predetermined time $(10,20$, $30 \mathrm{~min}$.) at $5.0 \mathrm{~V}$. At the end of the electrolytic treatment, a shutter placed at the bottom of the electrolysis cell was opened, and the electrolyzed water was added to $20 \mathrm{~L}$ of spent bathwater. The reasons why the electrolysis cell is installed in a tank containing the spent bathwater are the prevention of temperature rise of the inside of electrolysis cell as well as the prevention of chlorine odor from drifting in a room.

\subsection{Laundry method}

Each type of water (each100 mL) and 10 steel balls were put into a washing bottle that was then immersed in warm water at $40{ }^{\circ} \mathrm{C}$ for $10 \mathrm{~min}$. Next, two pieces of artificially soiled fabrics cut to the size of $5 \times 5 \mathrm{~cm}$ were added, and "washing" was performed for $30 \mathrm{~min}$ under conditions of $40^{\circ} \mathrm{C}$ and $42 \mathrm{rpm}$ using a Launder-O-Meter (Washing Fastness Tester) type KL-8 made by Koashokai Co., Ltd. In the case of using a detergent in "washing," JAFET standard detergent (polyoxyethylene alkyl ether, $16 \mathrm{wt} \%$ ) as a non-ionic surfactant was used. This detergent is neutral without the blending of alkali agent. "Rinsing" was applied with a batch method and the washed fabrics were dried in the air after the end of "rinsing."

\subsection{Measurement}

\subsubsection{Evaluation of detergent efficiency}

A Shimadzu UV-3100 spectrophotometer (Shimadzu, Kyoto, Japan) equipped with an integrating sphere was used to measure the reflectance of the samples at $530 \mathrm{~nm}$ after drying. Detergent efficiency was calculated as follows :

Detergent efficiency $(\%)=\left\{\left(R_{\mathrm{W}}-R_{\mathrm{S}}\right) /\left(\mathrm{R}_{0}-\mathrm{R}_{\mathrm{S}}\right)\right\}$

where

$R_{0}=$ surface reflectance of white fabric before soiling

$R_{\mathrm{S}}=$ surface reflectance of soiled fabric

$R_{\mathrm{W}}=$ surface reflectance of artificially soiled fabric after laundering 
All experiments were conducted four times and the average values were reported.

\subsubsection{Enumeration of viable bacteria}

A standard agar medium for general bacteria was prepared by autoclaving an aqueous solution of $0.5 \mathrm{w} / \mathrm{v} \%$ yeast extract (Becton Dickinson), $1.0 \mathrm{w} / \mathrm{v} \%$ pepton (Becton Dickinson), $0.5 \mathrm{w} / \mathrm{v} \%$ sodium chloride, and $1.5 \mathrm{w} / \mathrm{v} \%$ agar at $121{ }^{\circ} \mathrm{C}$ for $15 \mathrm{~min}$. Approximately $20 \mathrm{~mL}$ aliquots of this medium were then poured into Petri dishes and allowed to cool for $30 \mathrm{~min}$. A washingout solution was prepared by autoclaving a solution of $0.85 \mathrm{w} / \mathrm{v} \%$ sodium chloride and $0.20 \mathrm{w} / \mathrm{v} \%$ Tween 80 (Sigma Chemical Co., Ltd.) at $121{ }^{\circ} \mathrm{C}$ for $15 \mathrm{~min}$.

After washing, the fabric samples were placed in containers and incubated at $37{ }^{\circ} \mathrm{C}$ for $20 \mathrm{~h}$. washing-out solution in a quantity of 5-times dilution was put into the vial container, and the mixture was agitated. The extract washed out from the fabric with the washing-out solution was dropped to standard agar medium by $0.1 \mathrm{ml}$ and $1.0 \mathrm{ml}$ respectively, and the media were treated with inverted incubation at $37^{\circ} \mathrm{C}$ for $46 \mathrm{~h}$. Finally, the colonies were counted and converted to viable colonies $/ 1.0 \mathrm{~mL}$ of sample solution. This measurement was conducted six times and the average value was shown.

\subsubsection{Contact angle}

A goniometer-type G-1 Erma contact angle meter (Erma Co., Ltd.) was used to measure the contact angle. A sample solution $(10 \mu \mathrm{L})$ was dropped on a film using a micro-syringe and its contact angle was measured after a fixed time (1 - $30 \mathrm{~min}$.).

\subsubsection{Foaming property}

Each type of water $(10 \mathrm{~mL})$ and a $0.26 \mathrm{v} / \mathrm{v} \%$ of JAFET standard detergent were placed in a test tube with an $8 \mathrm{~mm}$ inner diameter and the mixture was then agitated at approximately 2,500 rpm for $1 \mathrm{~min}$ using a TM-2Ftype agitator (AS ONE Corporation). After allowing the samples to stand for $1 \mathrm{~min}$, the photographs were taken.

\subsubsection{Odor test}

A $5 \times 15 \mathrm{~cm}$ piece of test fabric (white cotton cloth) was placed in a $30 \mathrm{~mL}$ vial with $3.0 \mathrm{~mL}$ of sample water. The vial was closed tightly and incubated at $37{ }^{\circ} \mathrm{C}$ for $24 \mathrm{~h}$. The odor concentration was then quantified using an Alabaster-UV (EKW-8603) semiconductor-type odor concentration meter (B\&H Corporation). As the first step, the sample was put into the inside of the odor sensor and it was stabilized by standing for $15 \mathrm{~min}$. By obtaining the difference between the values before and after setting the sample, the index corresponding to odor concentration was calculated.

An odor test based on sensory evaluation was also conducted by 18 healthy female college students aged 20 to 22. The content of the sample was not disclosed beforehand, and the odor level was evaluated using the following scale :

0 : No odor

1: Slight odor (detection threshold)

2: Odor

3 : Strong odor

4: Bad odor

5 : Very bad odor

Average values were used for all subsequent analyses. As for sensory test, a double blind test, where both of observers and monitors are not informed of the content, was adopted in order to prevent observer bias.

\subsubsection{Free residual chlorine concentration}

The DPD method (Sibata Scientific Technology Ltd.) was used to measure the free residual chlorine. Briefly, $0.12 \mathrm{~g}$ of DPD ( $N, N$-diethyl- $p$-phenylenediamine) was added to $10 \mathrm{~mL}$ of a test solution, and the color after $5 \mathrm{~s}$ was determined using standard colorimetric plates [11].

\section{Results and discussion}

\subsection{Detergent efficiency of spent bathwater mixed with electrolyzed water}

The effects of adding electrolyzed water to spent bathwater were investigated. Table 2 shows the detergent efficiency when artificially soiled fabrics were washed. The detergent efficiency of the $0.5 \mathrm{~N} \mathrm{HCl}$ aqueous solution used in electrolysis without added detergent did not differ greatly from that of untreated bathwater or distilled water. However, when a $1.0 \mathrm{~N}$ electrolyzed $\mathrm{HCl}$ aqueous solution or above was added to spent bathwater, the detergent efficiency dropped by approximately $6 \%$ when compared to untreated bathwater.

When JAFET standard detergent was added to $\geq$ $1.0 \mathrm{~N}$ electrolyzed $\mathrm{HCl}$ aqueous solutions at $0.13 \mathrm{v} / \mathrm{v} \%$, the detergent efficiency dropped by $3-9 \%$ when compared to the controls. However, when compared to an electrolyzed $\mathrm{HCl}$ aqueous solution that had not been treated, the detergent efficiency increased by $7-12 \%$. When $0.26 \mathrm{v} / \mathrm{v} \%$ detergent was added to $0.5-1.0 \mathrm{~N}$ electrolyzed $\mathrm{HCl}$ aqueous solutions the detergent efficiency did not differ greatly from that of untreated spent bathwater and distilled water. However, when the concentration of the electrolyzed $\mathrm{HCl}$ solution was increased to $2.0 \mathrm{~N}$ or $3.0 \mathrm{~N}$, the detergent efficiency decreased by $5-8 \%$ compared to that of untreated spent bathwater. Overall, these findings indicate that addition of a high concentration of electrolyzed $\mathrm{HCl}$ solution to spent 
Table 2 Detergent efficiency of artificially soiled fabrics washed in leftover bathwater with electrolyzed water.

\begin{tabular}{|c|c|c|c|c|c|c|c|}
\hline \multirow{4}{*}{$\begin{array}{l}\text { Detergent }^{* 2)} \\
\text { concentration } \\
(\mathrm{v} / \mathrm{v}(\%))\end{array}$} & \multirow{4}{*}{$\begin{array}{l}\text { Untreated } \\
\text { spent } \\
\text { bathwater }\end{array}$} & & & & & \multicolumn{2}{|c|}{$(\text { Unit: } \%)^{* 1)}$} \\
\hline & & \multicolumn{5}{|c|}{ Spent bathwater with electrolyzed water } & \multirow{3}{*}{$\begin{array}{c}\text { Distilled } \\
\text { water }\end{array}$} \\
\hline & & \multicolumn{5}{|c|}{ Concentration of $\mathrm{HCl}$ aqueous solution as electrolytes } & \\
\hline & & 一 & $0.5 \mathrm{~N}$ & $1.0 \mathrm{~N}$ & $2.0 \mathrm{~N}$ & $3.0 \mathrm{~N}$ & \\
\hline Non-additive & 9.5 & & 7.6 & 3.1 & 4.2 & 3.2 & 6.5 \\
\hline 0.13 & 19.9 & 16.6 & 19.1 & 13.9 & 11.2 & 15.7 & 19 \\
\hline 0.26 & 24.6 & 25.1 & 25.2 & 23.3 & 16.8 & 19.5 & 25.3 \\
\hline
\end{tabular}

Artificially soiled fabrics: Made by The Laundry Research Association of Japan

*1) Detergent efficiency $(\%)=((\mathrm{Rw}-\mathrm{Rs}) /(\mathrm{Ro}-\mathrm{Rs})) \times 100$

$\mathrm{Rw}$ : Reflectance of fabrics after washing

Rs: Reflectance of fabrics before washing

Ro: White fabrics

*2) JAFET standard detergent: Poly(oxyethylene) Alkyl Ether

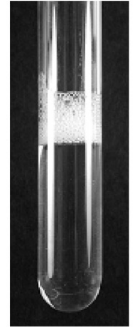

Untreated spent bathwater

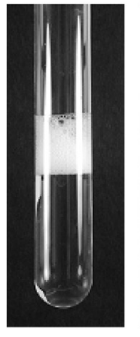

$-$

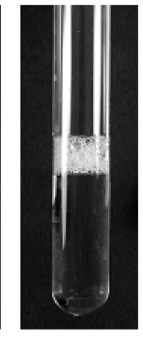

$1.0 \mathrm{~N}$

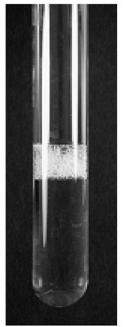

$2.0 \mathrm{~N}$

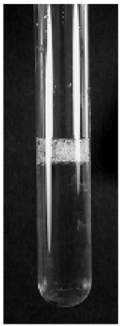

$3.0 \mathrm{~N}$

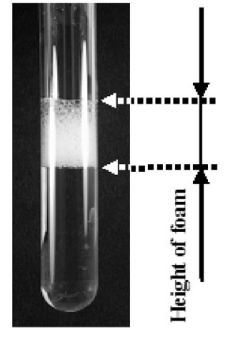

Distilled $w$ ater

Concentration of $\mathrm{HCl}$ aqueous solution as electrolytes

Fig. 1 Foaming index of spent bathwater with electrolyzed water containing JAFET standard detergent of $0.26 \mathrm{v} / \mathrm{v} \%$ (spent bathwater: $20 \mathrm{~L}$, electrolyzed water : $25 \mathrm{~mL}$ ).

bathwater leads to a great decrease in detergent efficiency.

\subsection{Reasons for decreased detergent efficiency}

Next, the foaming of a surfactant against spent bathwater mixed with an electrolyzed $\mathrm{HCl}$ aqueous solution was examined. Fig. 1 shows the foaming observed when $0.26 \mathrm{v} / \mathrm{v} \%$ JAFET standard detergent was evaluated. When the $\mathrm{HCl}$ aqueous solution was $0.5 \mathrm{~N}$, the foaming property did not differ greatly from that of untreated spent bathwater or distilled water. Conversely, when the concentration of the $\mathrm{HCl}$ aqueous solution was $\geq 1.0 \mathrm{~N}$, the foaming property clearly decreased. Additionally, these trends were more obvious for 0.26 $\mathrm{v} / \mathrm{v} \%$ detergent than for $0.13 \mathrm{v} / \mathrm{v} \%$ detergent. This fact suggested that hypochlorous acid generated by electrolytic treatment decreased in foaming property.

The detergent efficiency also decreased if spent bathwater mixed with electrolyzed water was used without added detergent (Table 2). Accordingly, although decomposition of surfactant by hypochlorous acid is one cause of decreased detergent performance, this alone cannot explain the observed decrease in detergent efficiency.

To examine the affinity between fabrics and spent bathwater mixed with electrolyzed water, the contact angles of various types of water were measured. As test waters, the spent bathwaters mixed with $1 \mathrm{~N}$ and $3 \mathrm{~N} \mathrm{HCl}$ aqueous solution. electrolyzed for $10 \mathrm{~min}$ and $30 \mathrm{~min}$, respectively, were used. As references, spent bathwater without adding electrolyzed water and distilled water were also used. For the measurement of contact angle, cellophane with the same cellulose molecular structure as cotton fiber, as well as polyester film of the same molecular structure as polyester fiber were used.

The time-dependent changes in the contact angle of various types of water against hydrophilic cellophane are shown in Fig. 2. The time-dependent changes in the contact angle of water against hydrophobic polyester film 


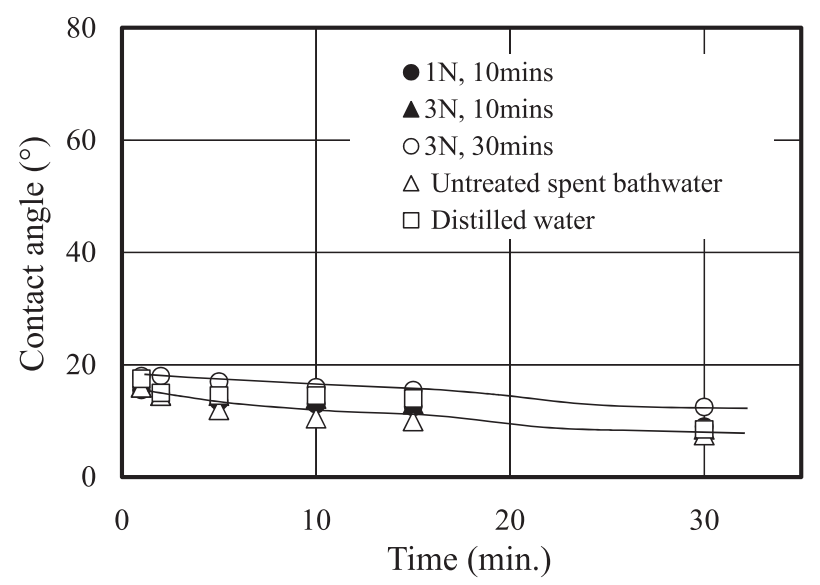

Fig. 2 Time dependence of contact angle of spent bathwater with electrolyzed water on cellophane.

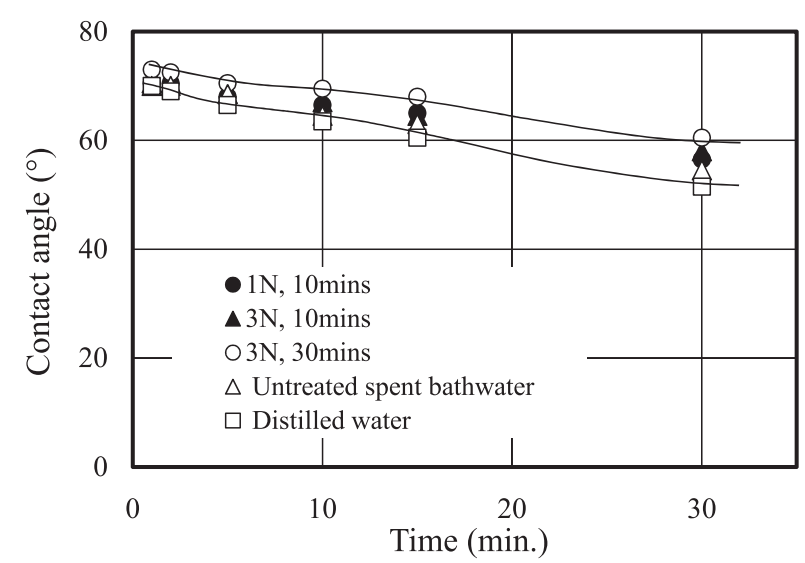

Fig. 3 Time dependence of contact angle of spent bathwater with electrolyzed water on polyester film.

are shown in Fig. 3. In both cases, spent bathwater mixed with electrolyzed water showed a higher contact angle than the controls. The contact angle of the bathwater mixed with $3.0 \mathrm{~N} \mathrm{HCl}$ aqueous solution electrolyzed for 30 min was much higher than that of the controls. These findings confirm that spent bathwater mixed with electrolyzed water has a low affinity for film materials, regardless of whether the materials were hydrophilic or hydrophobic. It is considered that when water with low wettability is used, washing water is hard to be absorbed into fiber inside and hard to be penetrated into the corner or deep part of fabrics. In addition, solubility of oily components and the like also decreases. For this reason, the use of water with low wettability for washing will give disadvantages to washing $[12,13]$. This probably contributed to the decrease in detergent efficiency observed when using spent bathwater. Furthermore, it is necessary to use various types of liquids with different detergent concentrations, in order to clarify changes in surface tension and critical micelle concentration. This would be an important research subject for the future.

\subsection{Effect of fiber material on laundry efficiency}

Table 3 shows the detergent efficiency after washing. The addition of electrolyzed water to spent bathwater resulted in decreased detergent efficiency when compared to untreated spent bathwater or distilled water. Additionally, although the artificially soiled fabrics were both made of cotton, the Testfabrics, Inc. fabric showed lower detergent efficiency than the Laundry Research Association of Japan fabric. The cause may be attributed to that the soil paste of the artificially soiled fabric made by Testfabrics, Inc. was mainly composed of oily dirt.

After washing, the artificially soiled wool fabric showed damage whenever any water was used. However, the detergent efficiency against wool was generally high when compared with other fabrics (Table 3). Conversely, little damage to fabrics other than wool was observed after washing. These findings show that the use of spent bathwater mixed with electrolyzed water for laundry did not lead to an increase in damage when compared to the controls.

\subsection{Sterilization effect of spent bathwater mixed with electrolyzed water used only for rinsing}

The previous paper reported that the use of spent bathwater mixed with electrolyzed water showed excellent sterilization effect against fabrics for laundry [4]. However, as mentioned in Section 3.1, this method had a defect of decreasing detergent efficiency. When spent bathwater mixed with electrolyzed water was used in laundry, it was necessary to utilize the excellent sterilization effect against fabrics for laundry, and at the same time, to keep detergent efficiency at the same level as the case using untreated spent bathwater or distilled water. Then, a trial was made as mentioned below: Untreated spent bathwater was used in "washing" and spent bathwater mixed with electrolyzed water was used only in "rinsing." The authors expected that this method would not decrease detergent efficiency, and would perform sufficient sterilization due to the action of hypochlorous acid. However, the method using spent bathwater mixed with electrolyzed water only in "rinsing" left the possibility of insufficient sterilization against bacteria attached to fabrics.

bathwater mixed with electrolyzed water only during rinsing on the concentration of general bacteria attached to the fabrics was examined (Table 4). The $\mathrm{pH}$ values and free residual chlorine concentrations of the spent bathwater generated in these experiments are shown in Table 4. On this occasion, spent bathwater with 0.26 $\mathrm{v} / \mathrm{v} \%$ of JAFET standard detergent was used in "washing." This JAFET standard detergent is made of 
Table 3 Detergent efficiency of different artificially soiled fabrics after washing in treated water.

\begin{tabular}{|c|c|c|c|c|c|}
\hline \multicolumn{2}{|c|}{ Artificially soiled fabrics } & \multirow{2}{*}{$\begin{array}{c}\text { JAFET standard } \\
\text { detergent } \\
\text { v/v(\%) }\end{array}$} & \multirow{2}{*}{$\begin{array}{c}\text { Untreated spent } \\
\text { bathwater }\end{array}$} & \multirow{2}{*}{$\begin{array}{l}\text { Electrolytic }^{* 1)} \\
\text { treated spent } \\
\text { bathwater }\end{array}$} & \multirow{2}{*}{ Distilled water } \\
\hline Fibrous materials & Maker & & & & \\
\hline \multirow{3}{*}{ Cotton } & \multirow{3}{*}{$\begin{array}{l}\text { The Laundry } \\
\text { Research } \\
\text { Association } \\
\text { of Japan }\end{array}$} & Non-additive & 7.35 & 6.2 & 6.97 \\
\hline & & 0.13 & 21.9 & 19.1 & 22.2 \\
\hline & & 0.26 & 26.4 & 21.3 & 25.5 \\
\hline \multirow{3}{*}{ Cotton } & \multirow{15}{*}{$\begin{array}{l}\text { Testfabrics } \\
\text { Inc. (U.S.) }\end{array}$} & Non-additive & 3.53 & 6.21 & 3.5 \\
\hline & & 0.13 & 11.6 & 10.1 & 15.0 \\
\hline & & 0.26 & 12.2 & 12.1 & 17.6 \\
\hline \multirow{3}{*}{ Polyester } & & Non-additive & 0.2 & 0.1 & 0.1 \\
\hline & & 0.13 & 24.2 & 23.5 & 24.6 \\
\hline & & 0.26 & 29.1 & 23.8 & 25.7 \\
\hline \multirow{3}{*}{ Silk } & & Non-additive & 3.92 & 0.4 & 11.2 \\
\hline & & 0.13 & 23.5 & 18.3 & 23.2 \\
\hline & & 0.26 & 26.6 & 26.5 & 26.8 \\
\hline \multirow{3}{*}{ Wool } & & Non-additive & 3.79 & 2.89 & 8.8 \\
\hline & & 0.13 & 39.8 & 25.7 & 51.9 \\
\hline & & 0.26 & 46.1 & 35.0 & 53.9 \\
\hline \multirow{3}{*}{ Acryl } & & Non-additive & 4.66 & 1.85 & 4.5 \\
\hline & & 0.13 & 11.9 & 18.2 & 27.1 \\
\hline & & 0.26 & 25.8 & 21.3 & 30.2 \\
\hline
\end{tabular}

* 1) Spent bathwater: $20 \mathrm{~L}$, Electrolyzed water: $25 \mathrm{ml}$

Table 4 Concentrations of viable general bacteria in fabrics rinsed with spent bathwater containing different types of electrolyzed water under various rinsing conditions after washing in untreated spent bathwater.

\begin{tabular}{|c|c|c|c|c|c|}
\hline \multirow{2}{*}{$\begin{array}{l}\text { Sample } \\
\text { (Spent bathwater with } \\
\text { electrolyzed water) }\end{array}$} & \multicolumn{2}{|c|}{$\begin{array}{c}\text { Condition of } \\
\text { electrolytic treatment }\end{array}$} & \multirow{2}{*}{$\mathrm{pH}$} & \multirow{2}{*}{$\begin{array}{l}\text { Free } \\
\text { residual } \\
\text { Chlorine } \\
(\mathrm{mg} / \mathrm{l})\end{array}$} & \multirow{2}{*}{$\begin{array}{l}\text { Viable bacteria } \\
\quad(\mathrm{CFU} / \mathrm{ml})\end{array}$} \\
\hline & $\begin{array}{l}\text { Concentration } \\
\text { of electrolytes } \\
(\mathrm{HCl} \text { solution) }\end{array}$ & $\begin{array}{l}\text { Time } \\
(\min .)\end{array}$ & & & \\
\hline $\begin{array}{c}\text { Untreated } \\
\text { spent bathwater }\end{array}$ & 一 & - & 7.32 & 一 & $9.35 \times 10^{3}$ \\
\hline Treated water -1 & $0.5 \mathrm{~N}$ & 10 & 5.90 & 2 & $\mathbf{0}$ \\
\hline Treated water -2 & $1.0 \mathrm{~N}$ & 10 & 4.79 & 6 & $\mathbf{0}$ \\
\hline Treated water -3 & $2.0 \mathrm{~N}$ & 10 & 4.17 & 20 & $\mathbf{0}$ \\
\hline Treated water -4 & $3.0 \mathrm{~N}$ & 10 & 3.97 & 23 & $\mathbf{0}$ \\
\hline Treated water -5 & $3.0 \mathrm{~N}$ & 20 & 3.56 & 60 & $\mathbf{0}$ \\
\hline Treated water -6 & $3.0 \mathrm{~N}$ & 30 & 3.37 & 90 & 6 \\
\hline $\begin{array}{l}\text { Washing } \mathrm{v} \\
\text { Washing } \mathrm{t} \\
\text { Rinsing tir }\end{array}$ & $\begin{array}{ll}\text { vater: } & \text { Spent bath } \\
\text { me: } & 30 \text { mins } \\
\text { ne: } & 30 \text { mins } \times\end{array}$ & $\begin{array}{l}\text { water wi } \\
\text { times }\end{array}$ & ET sta & deterg & $\mathrm{v} / \mathrm{v}(\%))$ \\
\hline
\end{tabular}

non-ionic surfactant, and known to have non-sterilization action. The treated waters $1-4$ used in "rinsing" were the spent bathwaters mixed with a different concentration of $\mathrm{HCl}$ aqueous solution. after electrolytic treatment. The treated waters $4-6$ were the spent bathwaters mixed with $\mathrm{HCl}$ aqueous solution. after electrolytic treatment for different time. As a reference, spent bathwater without treatment was used in "rinsing." These waters were used only in "rinsing," and the number of viable bacteria attached to fabrics for laundry was compared. As for "rinsing," the time for rinsing was set at 3 min per 1 cycle, and 2 cycles of "rinsing" were performed using new water.
When untreated spent bathwater was used for rinsing, $9.35 \times 10^{3} \mathrm{CFU} / \mathrm{mL}$ of general bacteria remained attached to the washed fabrics. Conversely, when spent bathwater mixed with $0.5-3.0 \mathrm{~N} \mathrm{HCl}$ electrolyzed aqueous solution was used for rinsing, no viable bacteria remained on the fabrics. In addition, even when electrolysis time was changed, viable bacteria were hardly recognized (treated water 4-6). Compared with the attachment of a number of viable bacteria such as $9.35 \times 10^{3} \mathrm{CFU} / \mathrm{ml}$ when spent bathwater without treatment was used, very high sterilization effect was proven. In other words, even when spent bathwater mixed with electrolyzed water was used only in "rinsing," sufficient sterilization effect was 
Table 5 Concentration of viable general bacteria in fabrics rinsed with spent bathwater containing electrolyzed water after washing in untreated spent bathwater.

\begin{tabular}{|c|c|c|c|c|}
\hline \multicolumn{3}{|c|}{ Condition of rinsing } & \multirow{2}{*}{$\begin{array}{l}\text { Viable bacteria } \\
\quad(\mathrm{CFU} / \mathrm{ml})\end{array}$} & \multirow[b]{2}{*}{ Note } \\
\hline Sample & $\begin{array}{c}\text { Time } \\
(\text { min.) } \\
\end{array}$ & $\begin{array}{l}\text { Cycle } \\
(-) \\
\end{array}$ & & \\
\hline \multirow{6}{*}{ Treated water $-2^{* 1}$ ) } & 3 & 1 & 0 & \multirow{6}{*}{$\begin{array}{c}\text { Living bacteria } \\
\text { in Untreated } \\
\text { spent } \\
\text { bathwater: } \\
9.15 \times 10^{3} \\
\text { CFU } / \mathrm{ml})\end{array}$} \\
\hline & 3 & 2 & 0 & \\
\hline & 3 & 3 & 1 & \\
\hline & 3 & 4 & 0 & \\
\hline & 6 & 1 & 0 & \\
\hline & 12 & 1 & 0 & \\
\hline & $\begin{array}{l}\text { Washing water: } \\
\text { Washing time: }\end{array}$ & \multicolumn{3}{|c|}{$\begin{array}{l}\text { Untreated spent bathwater with } 0.26 \mathrm{v} / \mathrm{v}(\%) \\
\text { of JAFET standard detergent }\end{array}$} \\
\hline & *1) $\mathrm{pH}: 4.79$ & \multicolumn{3}{|l|}{ Free residua } \\
\hline
\end{tabular}

recognized against fabrics for laundry.

The effects of rinsing conditions on sterilization were also examined. Table 5 shows the number of total bacteria attached to fabrics after washing using different rinsing times. The results showed that even when very short rinsing cycles were used (e.g., one cycle for $3 \mathrm{~min}$ ), no viable bacteria remained.

Even though washing was conducted using untreated spent bathwater, rinsing using the spent bathwater mixed with electrolyzed $\mathrm{HCl}$ aqueous solution very effectively sterilized the fabrics. These findings indicate that the concentration of $\mathrm{HCl}$ aqueous solution used in the electrolytic treatment was sufficient, even at $0.5 \mathrm{~N}$, as was a short rinse time of $3 \mathrm{~min}$.

\subsection{Deodorant effect of spent bathwater mixed with electrolyzed water}

Table 6 shows the odors measured using an odor concentration meter and the results of sensory odor testing. The odor concentration meter revealed a decrease in the odor index of 50 (based on comparison with the controls) when used bathwater containing $0.5 \mathrm{~N} \mathrm{HCl}$ aqueous solution was evaluated. When the $\mathrm{HCl}$ concentration was increased to $1.0-3.0 \mathrm{~N}$, the odor index decreased by an additional 30 units. Additionally, no difference in the odor index was observed among samples treated with concentrations ranging from $1.0 \mathrm{~N}$ to $3.0 \mathrm{~N}$, and the values of samples treated using these concentrations were nearly identical to those of samples treated with distilled water.

Sensory testing based on monitors revealed that rinsing with the controls resulted in a very high odor level of $>3$. However, rinsing with spent bathwater mixed with electrolyzed $\mathrm{HCl}$ aqueous solution resulted in odor levels between 1 and 2 ( $p<0.05)$. Additionally, as the concentration of $\mathrm{HCl}$ increased, the odor levels of the test fabrics decreased.

These findings indicate that treatment of spent bathwater with electrolyzed $\mathrm{HCl}$ aqueous solution led to decreased odors. Therefore, electrolytic treatment can be used to reduce the malodor of clothing when spent bathwater is used for laundry. In the future, the authors will examine agents other than $\mathrm{HCl}$ to identify an easier treatment process.

\section{Conclusions}

Washing using spent bathwater mixed with electrolyzed water was conducted to examine the effects of electrolyzed water on detergent efficiency, sterilization, and odor.

(1) Spent bathwater mixed with electrolyzed water was used to wash fabrics for $30 \mathrm{~min}$. The detergent efficiency of the washed fabrics decreased by about

Table 6 Evaluation of the odor emitted from fabrics soaked in spent bathwater with different electrolyzed waters after incubation $\left(37^{\circ} \mathrm{C}, 24 \mathrm{~h}\right)$.

\begin{tabular}{|c|c|c|c|c|c|c|c|}
\hline & \multirow{3}{*}{$\begin{array}{l}\text { Untreated } \\
\text { spent } \\
\text { bathwater }\end{array}$} & \multicolumn{5}{|c|}{ Spent bathwater with electrolyzed water } & \multirow{3}{*}{$\begin{array}{l}\text { Distilled } \\
\text { water }\end{array}$} \\
\hline & & \multicolumn{5}{|c|}{ Concentration of $\mathrm{HCl}$ aqueous solution as electrolytes } & \\
\hline & & - & $0.5 \mathrm{~N}$ & $1.0 \mathrm{~N}$ & $2.0 \mathrm{~N}$ & $3.0 \mathrm{~N}$ & \\
\hline $\begin{array}{l}\text { Odor concentration } \\
\text { meter }\end{array}$ & 160 & 136 & 109 & 78 & 79 & 74 & 85 \\
\hline Sensory test ${ }^{2}{ }^{2}$ & 3.7 & 3.5 & $1.9^{*}$ & $1.9^{*}$ & $1.7^{*}$ & $1.3 *$ & $0.8^{*}$ \\
\hline
\end{tabular}

1) "Alabaster-UV (EKW-8603)" from B\&H Corporation

2) 0 : No odor

1: Slight odor (detection threshold)

2: Odor

3: Strong odor

4: Bad odor

5: Very bad odor

${ }^{*} \mathrm{p}<0.05$ 
$5 \%$ when compared to samples washed using spent bathwater without electrolyzed water. These changes were correlated with an $8-10 \%$ decrease in foaming and decreased affinity between fabrics and washing water.

(2) To obtain sufficient sterilization without decreasing the detergent efficiency, spent bathwater was used for washing, and spent bathwater mixed with electrolyzed water was only used for rinsing. Under these conditions, even short rinsing times (one cycle for $3 \mathrm{~min}$ ) resulted in sufficient sterilization of fabrics.

(3) Odor testing of fabrics conducted using an odor meter and sensory testing both indicated that the odor of test fabrics decreased remarkably in response to the addition of electrolyzed water to spent bathwater. These findings suggest that it is possible to eliminate malodor derived from miscellaneous bacteria, via a suitable electrolytic treatment, when spent bathwater is used in washing.

\section{Acknowledgement}

We would like to thank President Ryosuke Kamei and Mr. Fumihiko Ando of Kokusai Eisei Co., Ltd., for their kind cooperation in providing samples and in measurement of physicochemical properties.

\section{References}

1. Japan Soap and Detergent Association, Research Report on the Actual Situation of Home Laundering, pp. 8-10 (2006).

2. A. Ishikawa, J. Okada, H. Kondo, Y. Takayama, K. Sunagawa, T. Enari, and Y. Ishii, J. Jpn. Asso. Infectious Diseases, 78, 898-904 (2004).

3. M. Irie, S. Yoshida, H. Miyamoto, and M. Ikeda, J. Occup. Health, 46, 68-77 (2004).

4. F. Racioppi, P. A. Daskaleros, N. Besbelli, A. Borges, C. Deraemaeker, S. I. Magalini, R. M. Arrieta, C. Pulce, P. Vlachos, Food Chem. Toxicol., 32, 9, 845-861 (1994).

5. Thomas A. Jackman, Carrie L. Hughes, Ground Water Monit Remediation, 30, 1, $72-76$ (2010).

6. M. Kouda, K. Marumo, K. Shoji, H. Matsushima, Jpn. Pharmacol. Ther., 36, 10, 893-898 (2008).

7. T. Shiraishi, Y. Nakagawa, Japanese J. Environ. Infect., 14, 4, 275-279 (1999).

8. M. Okamoto, Y. Komagata, K. Komiyama, S. Okuda, Y. Nishimoto, M. Kamoshida, and T. Nakamura, Bokin Bobai, 34, 3-10 (2006).

9. S. Yi-Cheng, L. Chengchu, and H. Yen-Con, ACS Symp. Ser. (Am. Chem. Soc.), 967, 309-322 (2007).

10. T. Takahashi, Y. Tsurunaga, Y. Aso, and T. Kondo, Sen'i Gakkaishi, 68, 156-163 (2012).

11. J. N. Jensen, and J. D. Johnson, J. Am. Water Works Assoc., 81, 59-64 (1989).

12. T. Hilgers, T. Bluhm, H. Kruessmann, Tenside Surfactants Deterg., 33, 1, 37-41 (1996).

13. Kissa E, Text. Res., 51, 8, 508-513 (1981). 